\title{
Challenges of Computer Science and IT in Teaching-Learning in Saudi Arabia
}

\author{
Hafiz Abid Mahmood Malik ${ }^{1}$, Faiza Abid ${ }^{2}$, R. Kalaichelvi ${ }^{1}$, Zeeshan Bhatti ${ }^{3}$
}

\begin{abstract}
:
Personal Computers (PCs) have invaded all ranges of civilization and there is currently a reasonable connection among technology, development and economic persistence. For a couple of decades in teaching-learning field, computer science curriculum development has been a core issue. In different eras different strategies have been adopted to improve the teachinglearning process. Integrated Curriculum Techniques (ICT) can play a positive role in all subjects. Specifically, strengthen the integration among all subjects can prove the good results in computer science and English language. In the area of computer science and information technology, communication in English language is considered a big barrier in understanding in Saudi Arabia. In this research we discuss and suggest the different aspects that can upsurge the overall performance and structure of the education system, particularly in Saudi Arabia. It is an effort to investigate the nature of hindrances and challenges faced at Saudi academies while implementing an IT based learning approach. To walk with the level of international universities and to play the role in modern scientific research, the use of the English language can improve the vision of computer science and information technology. Teacher-student communication in English language is a very important factor. This small step-forward can develop the confidence in students that consequently leads to the betterment of whole education system. Besides, the availability of up-to-date and accurate software and hardware installation is very important to cope with the challenges of the era. World is in your hands, if you know the proper use of technology. In this paper, Makerspace techniques have also been suggested that can play a significant role in teaching-learning that relates with ICT.
\end{abstract}

Keywords: Computer science; Infrmation technology; Makerspace; Education; Challenges; Curriculum; English language skills.

\section{Introduction}

The Ministry of Higher Education (HEC) in Saudi Arabia has encouraged the implications of Information Technology for teaching-learning among the students and teachers. Computer Science (CS) and Information Technology (IT) as speculative disciplines that deliver knowledge and proficiency substance for all hi-tech developments. Contrasting to other more stagnant disciplines, CS and IT are continuously being reformed. Innovations and new technologies continue to increase our indulgent of what computer scientists can do and how much our lives can be relaxed [1]. Knowledge of CS and IT are currently much vital to today's scholars as any of the customary sciences. Computers have subverted all extents of civilization and there is now a clear link among technology, revolution and economic existence. Deficiency of general curriculum standards, consistent and cogent teacher accreditation requirements remain to hamper the ability to ensure that students are effectively prepared to compete in this progressively high-tech world. This is the era

${ }^{1}$ AMA International University Bahrain

${ }^{2}$ King Khalid University, Saudi Arabia

${ }^{3}$ University of Sindh

Corresponding Email: hamalik@amaiu.edu.bh SJCMS | P-ISSN: 2520-0755 | E-ISSN: 2522-3003 ( 2018 Sukkur IBA University - All Rights Reserved 
of science and technology. New innovations have changed the trend of the education now, and without a PC no one can complete his research, as you need internet all the time for the research and originations [2]. To be in touch with the new trends and global issues in all fields of education, everyone is requiring fundamental knowledge of computer and internet, at least. On the other hand, CS extents a wide range of computing activities from academic grounds to automation, computer visualization, smart and intelligent systems, nanotechnology and bioinformatics. It is a study of computers, hardware, software designs, their applications, and their influence on a society. In this study, different obstacles in the way of CS and IT teaching are discussed are some remedies are given to avoid those obstacles. Main locale of the study is Saudi Arabia. The study has discussed the ways to improve the teaching-learning abilities. Students should be prepared to compete in the increasingly technological world and they should be familiar with practical implementation in the real world problem.

\section{Literature Review}

From a survey report (Sloan Consortium Survey) about online education in US, in year 2011, Rebecca stated that online enrolments evaluation is ten times higher than traditional mode [3]. Furthermore, computer education is an essential part of the online education.

Due to electronically support education and training pedagogy for student hub and collective learning has turned into familiar. Elearning is a totally new learning platform for students and teachers, therefore, computer skills are involving for its implementation. Due to evolutions in Information Communication Technology (ICT), students study or learn without schools' places; therefore, teachers' responsibilities and students' learning practices are also changing [4].

Knowledge and skills are sources of success and needed in current education system (primary schools, high schools and higher secondary schools) all over the world. According to R. Sims, e-learning model is new practice of learning and activity which improved and transformed traditional style of learning in the form of well-organized, effective and attractive new technology models [5].

The government of Pakistan in the province of Khyber Pakhtunkhwa, initiated IT Labs and laptop schemes, the KP pilot project distributed 2800 tablets to teachers but elearning concept, understanding and policy for the learning in KP are still remaining problems [6]. Government only just focused on hardware rather than utilization of ICT for education.

Learners can get opportunities and enhance their knowledge from blended learning which combines face-to-face and online mode of instruction [7]. Below some philosophies of CS and IT in teaching learning are discussed.

\section{Some philosophies of Computer Science and Information Technology in teaching-learning}

Below are some important philosophies of computer science and information technology that should be considered in teaching-learning environment:

- Scholars should gain an extensive synopsis of the field to build a broad image of CS and IT as a discipline.

- Students should comprehend not only the theoretical reinforcements of these disciplines but also learn how that theory affects practice.

- CS and IT education should emphasis on problem unraveling and algorithmic philosophy.

- Concepts should be educated liberated of explicit applications and software design.

- Scholars should be trained what will be anticipated from them in "real world" precisely, what is truly required to compose and retain computer programs

Sukkur IBA Journal of Computing and Mathematical Sciences - SJCMS | Volume 2 No. 1 January - June 2018 ( ) Sukkur IBA University 
and large software systems. CS and IT should be educated using real-world problems and applications instead of specific academic tools.

CS and IT education should comprise integrative and interdisciplinary acquaintance.

\section{Methodology and Challenges}

Although marvelous efforts have been exercised to improve the teaching-learning process of computer science and information technology but these could not produce the required outcomes. Below are some challenges that should be addressed while teaching-learning and these techniques can be utilized to achieve the above-mentioned objectives.

\subsection{Curriculum development}

It is very important to develop an up-todate curriculum of computer science and IT which fulfills the recent requirements of the subjects. An advanced curriculum always attracts the sensible students who desired to walk with the world. A country should have to design and implement general CS academic programs in order to better formulate their students for the progressively reasonable universal economy and current trends [8].

\subsection{Integrated curriculum}

Integration is the association of teaching substance to interconnect or unify subjects frequently taught in distinct academic courses or departments. In 1980s and 1990s, "curriculum integration" was stated as interdisciplinary, multidisciplinary and transdisciplinary curriculum designs. Pioneering educationalists concerned with improving student accomplishment are seeking ways to create rigorous, relevant, and engaging syllabus [9]. An incorporated and integrated curriculum work regarding association, it may be in real life or crossways the disciplines, regarding abilities or about understanding and knowledge [10] [11]. It rages subject varieties, capabilities and real life familiarity together to make a more accomplishing and perceptible learning environment for learners. Another motive of an incorporated syllabus is that it compromises more recurrence of knowledge than to teach subjects in segregation [12]-[13]. So, there must be integration among all subjects regarding CS and IT.

\subsection{Language skill}

Communication is a significant part of teaching-learning process. Though we can communicate in any language to teach the students (e.g Arabic in Saudi Arabia) but we must see the international trends to teach on international standards. English is an international standard language that is mostly being used in all over the world's best institutions and mainly in research. Therefore, to cope with recent trends and research in teaching-learning environment communication must be in English language.

\subsection{Computer labs}

Up-to-date hardware and software equipped computer labs are necessary to accomplish and teach the subject of computer science and information technology. Proper computer networking is required to better control the computer systems as well as students. Furthermore, e-learning labs should be facilitated separately.

\subsection{Interactive learning}

It is a more hands-on, real-world process of relaying information in classrooms. Interactive instructional techniques discourse the need for pupils to be active in the learning practice and to interact with others. Scholars can reinforce their knowledge about coaching by interacting with you and with their colleagues. Interactive instructional stratagems provide chances for students to reinforce their observational skills, listening skills, communication skills, and interpersonal skills.

\subsection{Deficiency of focusing on skill development}

It has been observed that students do not emphasis on developing skills rather they 
focus on rote learning. In general, most of the students excel when examinations emphasis mainly on memorization and rote learning. Besides this, they do not do well when assessments / papers contain critical thinking questions, creativity, tricky methodology, or logical problem solving. Students should focus on skill development as well instead of rote learning.

\subsection{Role of makerspaces in teaching- learning activities}

Makerspaces is the idea to provide separate places for teachers, students and researchers where they can share technology, ideas and knowledge to produce innovations. Through these collaborated work places many people can get new ideas and benefits in term of removing their confusions and to get more motivations towards their advance projects. Most of the time the quality of work is better in team work or in other words, more brains produce better ideas. So, Makerspaces are the good idea for the quality work. In every institution particularly in research oriented institutions there should be a Makerspace for the teaching-learning environment. Furthermore, it somehow cut the cost of research and technology equipment compare to individuals. Makerspace idea can be facilitated and implemented in form of separate e-learning labs.

\subsection{Creating awareness of blended learning methods}

Blended teaching is more constructive method than purely face-to-face classes. Blended instruction [14, 18] is a mixture of digital instruction and one-on-one face instruction in a traditional classroom environment. By combining information technology into class projects, students will be able to have better understanding of course material. Eventually, the students will be motivated to learn computer science and Information technology subjects and they implement the practical knowledge of computer science in to other subjects. Additionally, weaker students can be given tutorial classes through online at their convenient time. Hence, the level of achievements is higher and effective in blended learning than face-to-face learning.

\subsection{E-learning}

E-learning is an interactive and flexible means of learning or getting information. Through E-learning, learning and teaching can happen at anytime and anywhere. The components of e-learning include text, audio, video and animation. Using E-Learning apps, students' motivation towards learning subjects can be boosted. Also, it allows students to enhance diversity, critical thinking for innovative problem solving. In other way, practice of E-learning makes faculty members familiar with current Internet trends and how they can be applied in the lessons. At the same time, it supports faculty members to generate their own courses and activities on the webbased platform.

Some of the E-learning tools: TalentLMS, Lessonly, Digital Chalk, Moodle, Socrative, Kahoot, TED-ED, Instructables, Hopscotch, Slack and uBoard digital interactive whiteboard [15-16]. By using the e-learning tools, the following activities can be incorporated through online.

- $\quad$ Problem - Solving Activities;

- $\quad$ Project - Solving Activities;

- $\quad$ Action - Based Strategies;

- Brainstorming;

- Questionnaires;

- Quizzes;

- Announcements;

- Forums.

\subsection{Web-based education}

The public in Saudi Arabia has been using internet since 1999. In this internet era $60 \%$ of the Saudi population are adapting emerging new technologies. Most of the Saudi universities use the traditional lecture based 
classroom teaching method with few programs having distance learning. In distance learning programs, they use web-based instruction [14, 18]. The web based instruction facilitates online teaching and learning methods. Nevertheless, only a limited number of faculties using online teaching methods, those who have adequate skills in e-learning. In order to increase the e-learning techniques in Saudi based universities, proper training should be provided to all faculties. Besides, female faculties have negative perspective using internet as it has immoral content. This perception lessens the adoption of web-based education. Furthermore, the faculty members with inadequate knowledge of internet usage find difficulty in adopting web-based education. To discourse these issues, Saudi based universities should provide proper awareness, support services and adequate training to both faculty members and the students. These factors improve the confidence in using web based technology either in delivery approach or in learning environment.

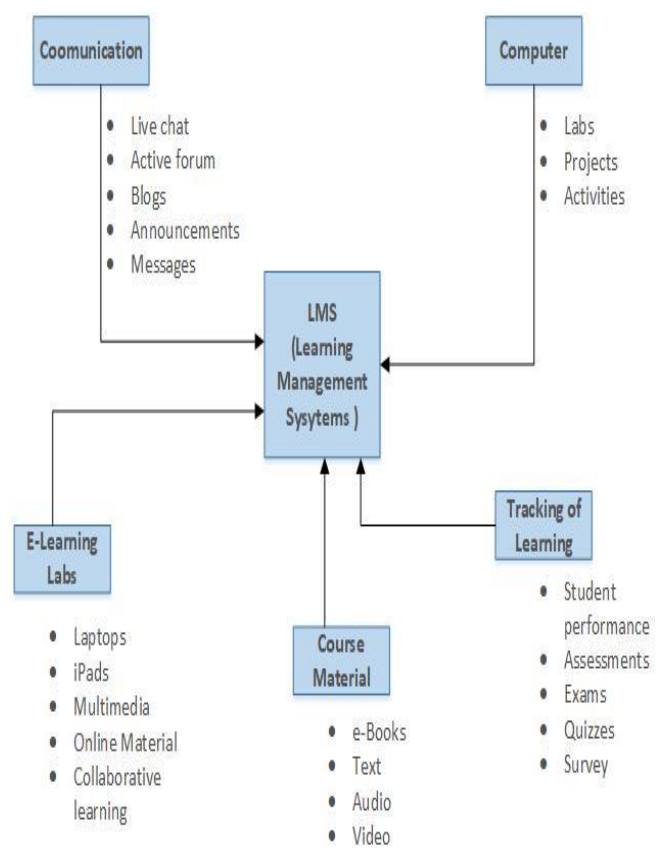

Fig. 1. Learning Management System.

\subsection{National E-learning and Distance Learning Centre (NELC)}

Universities shall provide digital educational system by using National Elearning and Distance Learning Centre (NELC) [14] established by the Ministry of Higher Education, Saudi Arabia. To implement e-learning in Saudi universities, NELC offers practical tools such as multimedia resources to empower faculties of universities to implement online teaching. NELC established "Jusur E- Learning Management System" (LMS) [17] to support teaching and learning system in Saudi universities. Jusur builds E-learning culture among the faculty members and the students. However, student discipline, responsiveness, and training of the LMS are the challenges in implementing Jusur. In addition, adequate training should be given to faculty members to use Jusur as their teaching strategy. Learning Management System (LMS) is shown in figure 1.

\subsection{Recommendations}

- Academic staff should be only well qualified teachers

- An up-to-date curriculum of computer science and IT should be implemented which fulfills the recent requirements of the subjects.

- Instead of teacher-centered activities there should be learner-centered environment.

- Integrated curriculum should be practiced for better teaching-learning.

- Teacher-student communication must be in English language.

- Using teaching techniques that integrate language skills rather than teaching them discretely.

- Examinations should be regarded as a teaching and learning device rather than being just a testing device.

\footnotetext{
Sukkur IBA Journal of Computing and Mathematical Sciences - SJCMS | Volume 2 No. 1 January - June 2018 @ Sukkur IBA University
} 
- Web-based education system can improve the quality of teachinglearning environment.

- E-learning technique can be helpful to enhance the educational standard.

- National E-learning and Distance Learning Centre (NELC) should be considered.

- National Center of e-learning and digital learning (NCeL) may be useful for improvements.

- Students can be categorized according to their learning skills.

\section{Results}

If authorities take the above suggestions into consideration then very positive outcomes are expected. Curriculum will be improved and there would be a proper integration among all subjects as well. Language skills of the students will be enhanced. Computer labs will be highly equipped and properly managed and utilized. In addition to students' development, teachers will also be improving their skills and overall teaching-learning environment will be positively affected.

\section{Conclusion}

World has become global village due to the advancements in technology. Computer science and information technology are the main pillars in these achievements. So, in this era, any country which does not get benefits from the science and technology will be backward. In the field of CS and IT teachinglearning is very important factor. Here, we have discussed some teaching challenges in the form of objectives and their remedies are suggested in the form of methods. Through the integrated curriculum techniques, we can upraise the quality of education. Further, by permanent communication in English language, student's confidence and his/her understanding caliber towards research and innovation can be enhanced. That would definitely be helpful in all subjects as well. By that we can prepare the student to compete with the challenges in the upcoming technologies. Our main focus is student to whom we aimed to give quality education and knowledge. So that he/she may be a part of a healthy society and could play his/her role in the betterment of the country and humanity. Furthermore, Makerspaces can be positive step towards research and innovations.

\section{REFERENCES}

[1] Stephenson C, Gal-Ezer J, Haberman B, and Verno A., "The new educational imperative: Improving high school computer science education," Final Report of the CSTA Curriculum Improvement Task Force, Feb 2005.

[2] Sotirofski K, Kukeli A, and Kalemi E., "Challenges Of Teaching Computer Science In Transition Countries: Albanian University Case," Journal of College Teaching and Learning, vol. 7, no. 3 pp. 79, March 2010.

[3] Rebecca A. Clay, "What you should know about online education," American Psychological Association, vol. 43, no. 6, pp. 42, June 2012. (accessed Jun 30, 2016).

http://www.apa.org/monitor/2012/06/onl ine-education.aspx.

[4] JISC, "E-Learning Pedagogy Programme," E-learning pedogogy JISC, https://www.jisc.ac.uk/rd/projects/elearning-pedagogy. (accessed June 20,2016).

[5] R. Sims, "Rethinking (e) learning: A manifesto for connected generations," Distance Education, vol. 39, no. 92, pp. 153-164, August 2008.

[6] KPESE, "IT Projects, Elementary \& Secondary Schools," KPESE, http://www.kpese.gov.pk/. (accessed June 30, 2016).

[7] L. G. Muradkhanli, "Blended learning: The integration of traditional learning and eLearning," 2011 5th International Conference on Application of Information and Communication Technologies (AICT), Baku Azerbaijan, pp. 1-4, 2011.

[8] Anderberg E, Nordén B, and Hansson B, "Global learning for sustainable development in higher education: recent trends and a critique," International Journal of Sustainability in Higher Education, 18; vol. 10, no. 4, pp. 368-78, Sep. 2009 . 
[9] Drake SM and Burns RC. Meeting standards through integrated curriculum. $A S C D, 2004$.

[10] Herazo Rivera JD, "Using a genre-based approach to promote oral communication in the Colombian English classroom," Colombian Applied Linguistics Journal, vol. 14, no. 2, pp. 109-26, Dec., 2012.

[11] Fogarty R, "Ten ways to integrate curriculum," Educational leadership, vol. 49 , no. 2 , pp. 61-5, Oct. 1991.

[12] Cooper S, Dann W, Pausch R. Teaching objects-first in introductory computer science. InACM SIGCSE Bulletin 2003 Feb 19 (Vol. 35, No. 1, pp. 191-195), ACM.

[13] Venkatesh, V., Morris, M. G., Davis, G. B., \& Davis, F. D. (2003). User acceptance of information technology: Toward a unified view. MIS quarterly, 425-478.

[14] Reem Alebaikan and Salah Troudi, "Blended Learning in Saudi Universities: Challenges and Perspectives," ALT-J, Research in Learning Technology, vol. 18, no. 1, pp. 49-59, March 2010.

[15] https://www.getapp.com/educationchildcare-software/education-elearning/, accessed on January 2018.

[16] http://blog.ed.ted.com/2015/09/19/25awesome-apps-for-teachersrecommended-by-teachers/, Accessed on January 2018.

[17] Hisam Barakat Hussein, "Attitudes of Saudi Universities Faculty Members towards using Learning Management System (Jusur)," The Turkish Online Journal of Educational Technology, vol. 10, no. 1, pp 43-53. April 2011.

[18] https://www.moe.gov.sa/en/TheMinistry/ Education/Pages/InitiativesandProjectsof TheMinistryofEducation.aspx AlMegren, A., \& Yassin, S. Z. (2013). 